\title{
INCORPORATING BLOGGING INTO AN EFL WRITING COURSE: AN ACTION RESEARCH
}

\author{
Anggri Muhtia ${ }^{1}$ \\ Nur Arifah Drajati ${ }^{2}$ \\ Universitas Sebelas Maret \\ JI. Ir. Sutami No. 36A, Surakarta, Jawa Tengah 57126, Indonesia \\ ${ }^{1}$ a.muhtia@unlam.ac.id * \\ ${ }^{2}$ drajatinur@gmail.com
}

*Corresponding author

Manuscript received 20 July 2017

Manuscript accepted 4 October 2017

\begin{abstract}
The application of blogs in English teaching and learning, especially in writing, has gained considerable attention. It combines learning activities with advanced Internet technologies and virtual social interaction. Assigning students to write online (blogging) outside classroom hours would enable students to learn in authentic social contexts and allow them to get exposed to authentic learning materials. The purpose of this study was to improve students' writing skill through incorporating blogging activity into an EFL writing course. The blogging activity was carried out on a social network website that provides a blog section in addition to many features. The members of the website (which is part of an English learning activity) can post their writing and give comments on each other's blog posts. In this study, mixed methods were applied in action research that integrated qualitative and quantitative data. The qualitative data were collected using observations and interviews, while the quantitative data were from test scores. The work was developed through two cycles. The findings showed that there was an improvement in students' writing skill and students' perceptions towards blogging were positive.
\end{abstract}

Keywords: blogging, writing skill, social constructivism, social network website

\section{Introduction}

Writing may be the most challenging activity in EFL classroom. Nepomuceno (2011) stated that writing appears to be the most difficult among the four language skills. Not only do students need to have an adequate vocabulary to convey their thoughts or ideas in written English, but they need to pay attention to grammar, spelling, and 
punctuation. Moreover, they should be able to make their composition cohesive and coherent to make it meaningful and understandable. Consequently, many English as a Foreign Language (EFL) students are hardly able to produce good writing due to the language limitation and poor writing skill.

That English is a foreign language makes it reasonable to consider it as the condition underlying the students' language limitation. Students rarely use English for daily communication and may only use it when learning it at school. Students' exposure to English as the target language then should be adequate to mitigate this issue. Internet technologies ease people to find a way to get in touch with English in a virtual world. When it is hard to find a way to communicate in English in the physical world, students can make it possible by involving themselves in virtual societies offering such possibility. Blogging, for example, can be utilised to support English teaching and learning. Nadzrah and Ismail (2011) emphasised that the language teaching and learning should not be secluded from society to enlarge the scope of language that students can learn.

The application of blogs in teaching and learning has received significant attention, including in writing. Zhang (2009) claimed that the potentials of blogs used for EFL writing class are huge. However, Ozdemir and Aydin (2015) found that blogging "is not superior to traditional pen-paper regarding writing achievement" ( $p$. 378). The schema of blog use in teaching and learning is by creating personal blogs in some blogging platforms, such as WordPress.org and Blogger.com (Ozdemir \& Aydin, 2015; Abu Bakar \& Ismail, 2011; Zhang, 2009). Such a mode may have some drawbacks, such as the audience limited to the students of the classroom when no attempts are made to attract other readers. Thus, the way the blogging activity carried out in this study was not through personal blogs but through a social network website, MyEnglishClub, whose members come from many countries. It allows its members to upload blog posts on the website which means that they can reach a wider audience. The research questions addressed in this study were if incorporating blogging activity into an EFL writing course improved EFL students' writing skill, and how student's perceptions towards blogging were.

\section{Literature Review}

\section{Blogging}

There are several definitions of blog or web blog proposed by researchers. Martindale and Wiley (2004) defined a web log as a website containing features that enable more effective web publishing by reducing the technical barriers. Armstrong and Retterer (2008) defined weblog as "a web page that contains a running log of commentaries, multimedia, and hyperlinks" (p. 234). Abu Bakar and Ismail (2011) explained that blogs are online personal journals to convey thoughts publicly in which the writers and readers can interact with each other by giving comments on the blog contents. The activity of writing ideas, opinions, and stories in blogs is called blogging.

Blogging has accepted growing popularity because the writing activity is carried out by utilising Internet technologies. Nepomuceno (2011) mentioned that 
one of the reasons explaining the popularity of Internet is its ability to make a quick connection among people in the world and allow them to share stories and ideas with one another.

\section{Social Constructivism}

The learning theory providing the basis for the use of blogs in teaching and learning process is the theory of Social Constructivism developed by Lev Vygotsky. Jennings, Surgenor, and McMahon (2013) stated that the emphasis of this theory is "on the collaborative nature of learning and the importance of cultural and social context" (p. 1). "Knowledge is not simply constructed, it is co-constructed" (Jennings et al., 2013, p. 4). Blogging is one of the potential activities that enable learning in social context to happen; the activity involves social interaction between students and teachers or among bloggers (the persons writing the blog contents). Student bloggers can get feedback from their peers, other bloggers, and definitely from their teachers. The feedback help them construct knowledge and strengthen or even reconstruct their previous understanding of knowledge. They also can read and observe others' discussion about the knowledge they are trying to construct or problems they are trying to solve. It can be said that they go through "the level of potential development as determined through problem solving under adult guidance or in collaboration with more capable peers" (Vygotsky, 1978, p. 97).

\section{Authentic Texts}

The potential of blogs in language teaching and learning have been discussed in many articles. Blogs not only promote the development of writing skill but also foster the development of reading skill. The writers (bloggers) and the readers are involved in an interactive communication, and both parties read and write either the blog posts or the comments. Nepomuceno (2011) stated that "Blogs provide authentic reading texts for learners to observe and analyze, making them aware of the conventions of writing - i.e. grammar, mechanics, unity, coherence, etc." (p. 96). Nunan (1999) asserted that the authentic texts result from genuine communication, not written purposely for language teaching. The authentic texts provide the means for learners to interact with the real language and content, and make the learners experience learning a language as it is used beyond the classroom (Kilickaya, 2004).

\section{Process-genre Based Approach}

In teaching writing, teachers should consider the approach used in the classroom. There are three approaches and one synthesised approach that teachers can use. The product based approach to writing concentrates on the linguistic knowledge and the final product. Nunan (1999) stated that this approach focuses on "tasks in which the learner imitates, copies, and transforms model provided by the teacher and/or the textbook" (p. 272). Many education practitioners, however, propose the process-based approach. Brown (2001) explained that the process approach to writing includes "the process of prewriting, drafting, revising, and editing" (p. 337). 
Meanwhile, Reppen (1995) argued that "[s]imply allowing students to write a lot will not necessarily provide sufficient practice in the types of writing valued for academic learning" (p. 32). He advocated a genre-based approach to writing.

Badger and White (2000) argued that "the conflict between the various approaches is misguided, and damaging to classroom practice" (p. 157). In fact, all approaches are complementary. They suggested a model of the process-genre approach, which is the synthesis of the three approaches, to be considered in teaching writing. Incorporating blogging activity into the writing course supports this approach; the students practice their writing skills through blogging and also learn by reading others' writing while the teacher provides the samples of the genre and the guidance of writing conventions to build students' awareness of the forms and patterns of language use.

\section{Methodology}

\section{Subjects and Research Methods}

The subjects of the study were 23 undergraduate nursing students of a public university in South Kalimantan Province, Indonesia. The students, consisting of 18 females and 5 males, were transfer program students; the ones already obtaining the associate degree in nursing but continuing their study to earn bachelor's degree. The subjects were classmates and most of them already had jobs as nurses.

In this study, action research was used as the research approach. "Action research is about taking action based on research and researching the action taken" (Ary, Jacobs, Sorensen, \& Razavieh, 2010, p. 512). They mention that this approach is used in education in several areas, such as "curriculum development, teaching strategies, and school reform" (Ary et al., 2010, p. 513). Teachers can do the action research to find out the teaching strategies working best and to discover the solutions to problems they are having in their classrooms.

Mixed methods were applied in this action research conducted in two cycles. It integrated quantitative and qualitative data; the quantitative data collected from test scores were used to see the progress of students' writing skill, while the qualitative data from observations and interviews were used to find out the strengths and weaknesses of each cycle and student perceptions towards blogging. One test was given at the beginning of cycle 1 and two tests at the end of each cycle, while observations were performed during the learning process, and interviews were carried out at the end of cycle 2 .

\section{Procedures}

The writing course was delivered in class using the process genre approach that emphasised both linguistic skills (prewriting/planning, drafting, revising and publishing), and linguistic knowledge, such as text structure and grammar. The descriptive genre was chosen because this type of text has some distinctive characteristics and is believed to be useful for students' jobs as nurses, such as when 
they have to describe a patient's disease symptoms, make the diagnosis, and describe part of the infected body.

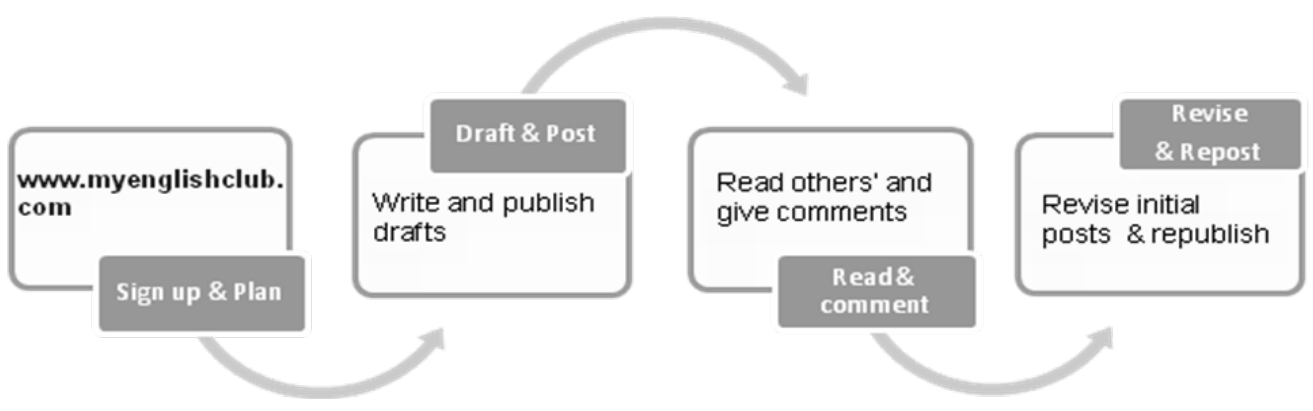

Figure 1. A diagram of steps in blogging activity

Students were asked to be members of a social network website, MyEnglishClub, which offers many features in addition to blogs, including online chat, photos, videos, forums, articles, and events that students can exploit to enhance their English. Since the members are not only people who like socialising but also English learners and teachers, one can call it an English learning website. The members come from different countries, and there are some English native speakers who actively contribute to the website.

Students accomplished their weekly assignments by writing blog posts in their pages. They had to choose the topic themselves because it was part of planning/pre-writing. In addition to assignments, the students were encouraged to compose free writing and to give comments on other members' posts. They also responded to the comments given by other members about their blog posts. In the Read \& Comment activity, the students carried out an analysis of texts written by other bloggers and were encouraged to get involved in the discussion that would benefit the students and the bloggers. After getting feedback, students had to revise their drafts and republish them.

\section{Data Collection and Analysis}

The preliminary test of writing was given before cycle 1 , and a posttest was given at the end of cycle 1 . The scores of posttest in cycle 1 were compared with the scores of pretest to find out if there was an improvement. Another test was given at the end of cycle 2, and the scores were compared with the scores of posttest of cycle 1. So, three tests were analysed to find out the improvement of students' writing skill in two cycles. Each cycle lasted three weeks and in each week there were two meetings, consisting of one-hour meeting for lectures and two-hour meeting for practice. The writing tests were teacher-made tests and graded by the teacher of the class.

The writing components some experts suggest to be used to measure students' writing skill include content, organization, vocabulary, grammar, and mechanics, using the analytical scoring profile suggested by Jacob et al. (1981). 
Table 1

Writing scoring profile

\begin{tabular}{lc}
\hline Component & Max. score \\
\hline Content & 30 \\
Organization & 20 \\
Vocabulary & 20 \\
Grammar & 25 \\
Mechanics & 5 \\
\hline Total & 100 \\
\hline
\end{tabular}

Each component of the students' writing was scored using a writing scoring rubric based on the scoring profile in Table 1, and converted using the following formula:

Score of each writing component $=\frac{\text { Gained score }}{\text { Maximum score }} \times 100$

For example: when the score for the content component that a student got was 15; it would be divided by 30 and multiplied by 100 as the total score, so the student's conversion score for the content component was 50. Such conversion was performed for data interpretation to see the improvement of each component of students' writing. Descriptive statistics were used to describe the highest score and the lowest score in the class, as well as the mean of students' writing scores.

The analysis of the qualitative data was performed using descriptive, interpretative technique. The research team discussed and interpreted the data from the observations and interviews, and the data went through data reduction, data display, and conclusion drawing.

\section{Limitation of the Study}

The topics for the writing should have focused on the area of nursing. However, considering the results of the pre-test which showed that the students' English proficiency level in writing was still low and the fact that they were transfer program students who had been away from school for some time, the writing topics were not merely about nursing but general topics with the aim of encouraging students to write in English and read English texts sufficiently. It was expected that they could enhance vocabulary, learn and use linguistic knowledge and linguistic skills in their writing. Moreover, the audiences in the social network website where the blogging activity took place are diverse, so the topics should not be limited to nursing subjects. 


\section{Results}

\section{Cycle One}

Planning and action. Author 1 was a teaching assistant/partner who assisted the lecturer in teaching English for nursing students at a public university in South Kalimantan Province, Indonesia. Since their major was not English, the core of the syllabus contents emphasized English for Specific Purposes (English for nursing), and thus the proportion of time for Academic writing was limited. There were four basic units covered in the syllabus for one semester: Speaking (nursing/medical subject), Reading (article analysis), Writing (descriptive text), and Debate. Because the objectives of Reading and Writing units supported one another, both units were combined. Before conducting the research, a test was carried out on the subjects to see the students' performance in writing.

In class, the teacher introduced some descriptive texts, and from those texts the content and organisation of the texts were discussed along with the writing conventions. Grammar, text structure, spelling, and punctuation were learned during the lecture meeting and discussed during practice, and students were asked to analyse them from the texts. The topics that the students could choose for their writing were general, such as describing a best friend, a garden, scenery, etc. They had to upload their work on their blog page on the website.

Students got feedback not only from the teacher but also from their peers and other members of the website. Although the three parties did not always contribute to every post students uploaded, at least they received feedback from the teacher. Each student had to revise the writing by considering those feedback. Teacher's feedback were given via email after some time, not immediately after students posted their drafts to allow discussion and the process of knowledge coconstruction to take place. They republished the revised writing on the same page. The final products and the writing revisions were taken into account.

When writing drafts and responding to comments, students could look up words or phrases in a dictionary, and then check them online to see whether the vocabulary or phrases were correct or commonly used in the context being discussed. Figures 2 to 5 show the process that a student' text went through from draft to final version.

\section{Lam's Cake}

Posted by on December 6, 2015 at 0:30

This is a cake from my town. We call it Lam's cake. This cake is very sweet, but delicious. It is made by burning and has a layer of very much. The person who makes this cake must be heat resistant and has extra patience. The composition is 10 grains duck eggs, sugar, milk, coconut milk and wheat. The price of the seed is more than one hundred thousand rupiahs. Expensive but according to taste. If you have diabetes, please dont eat too much this cake or your blood sugar will be high. It is cake from my town, let's to try it guys ;)

Figure 2. A copy of an initial blog post 
Comment by Elen on December 7, 2015 at 8:39

Mmmm, it looks very delicious!

Comment by Icha on December 7, 2015 at 5:34

Hi Dewi Risma, We usually call it "Kue Lapis" or Lapis Cake" because it has a layers every inch that compose this cake. Yes the taste is very sweet and it relevant with the price (expensive). If I eat this cake I have to drink more water to neutralize the sweetness of this cake for my tongue.

Comment by noaslpls on December 6, 2015 at 5:30

Looks like a 'kek lapis - layered cake' which is very famous over in Sarawak. Apparently it takes a long time to make one cake because it has many layers and it needs to be bake slowly.

Comment by usra riasat on December 6, 2015 at 5:21

Thankx Dewi for sharing this, I also love to bake cake....:

I'll share my baking recipe some other time.

Comment by dara gino on December 6, 2015 at 4:50

Kabar kamu bagaimana Dewi Risma? Saya mau Lam cake, saya mau makan dua. tetapi kenapa kamu tidak menambahkan saya? I want two cakes from there. I hope you add me to your friends.

Comment by Lady Noor on December 6, 2015 at 1:37

This is a cake from my town. We call it Lam's cake. This cake is very sweet, but delicious(I think you meant to say "This cake is too sweet but delicious"). It is made by burning and has a layer of very much (I bet you meant to say "and it has a big layer" maybe you meant to say something else, but it's not clear what you meant to say). The person who makes this cake must be heat resistant, and has extra patience. The composition is 10 grains duck eggs, sugar, milk, coconut milk and wheat. The price of the seed (seed of what?, not clear) is more than one hundred thousand rupiahs. Expensive but according to taste(Expensive but the taste worths it). If you have diabetes, please don't eat too much of this cake rr otherwise your blood sugar level will be get high. It is a cake from my town, let's to try it guys ;)

Very good, with minor mistakes but yet understandable, keep writing, dear.

Figure 3. Comments from the website members

\section{Lam's Cake}

Posted by

This is a cake from my town. We call it Lam's cake. This cake is very sweet, but delicious. It is made by burning and has a layer of very much. The person who makes this cake must be heat resistant and has extra patience. The composition is) 10 grains duck eggs, sugar, milk, coconut milk and wheat. The price of the seed is more than one hundred thousand rupiahs. Expensive but according to taste. If you have diabetes, please dont eat too much this cake or your blood sugar will be high. It is (cake) from my town, let's to try it guys ;)
Comment [D35]: Lam Cake (no need an apostrophe and s)

Comment [D36]: Lam cake (no need apostrophe and s)

Comment [D37]: baking

Comment [D38]: many layers

Comment [D39]: The ingredients are

Comment [D40]: Do you mean "butir"? Grain is for the seed of crop/plant, not for egg. Omit 'grains', and just write "ten duck eggs".

Comment [D41]: wheat flour

Comment [D42]: Do you mean "the seed" is forbiij" sebiil kue? We cannot use it forcake.

Comment [D43]: worth a taste

Comment [D44]: 'don't'. You forgot putting the apostrophe between the $n$ and $t$ (but we should avoid contractions in formal writing)

Comment [D45]: eat this cake too much (after the verb, put the object before the adverb)

Comment [D46]: a cake

Comment [D47]: no need "to" after let's

Figure 4. Teacher comments 


\section{Lam Cake}

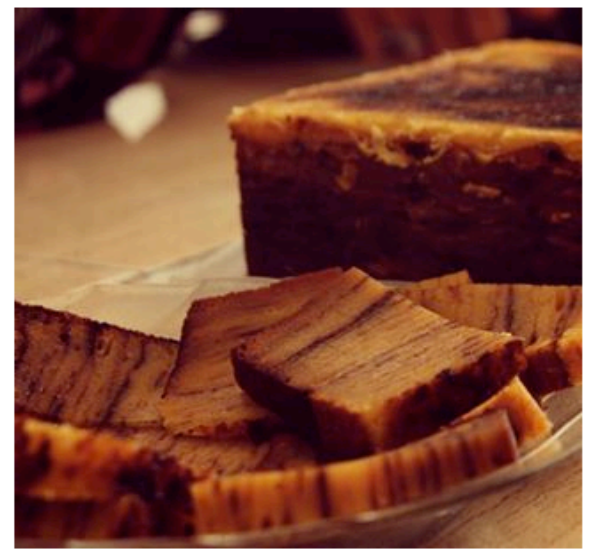

This is a cake from my town. We call it Lam cake. This cake is very sweet, but delicious. It is made by baking and has many layers. The person who makes this cake must be heat resistant and has extra patience. The ingredients are 10 duck eggs, sugar, milk, coconut milk and wheat flour. The price of each slice is more than one hundred thousand rupiahs, expensive but worth a taste. If you have diabetes, please don't eat this cake too much or your blood sugar level will get high. It is a cake from my town, let's try it guys ;)

Figure 5. The final version

Observation and reflection. The scores of the posttest in cycle 1 for all writing components increased. Grammar and mechanics were below 60. For the first week, students apparently still tried to learn how the website operated and some explored other features available on the website.

Table 2

Students' average scores of pretest and posttest 1 viewed from each writing component

\begin{tabular}{lll}
\hline Component & \multicolumn{2}{c}{ Score } \\
\cline { 2 - 3 } & Pretest & Posttest 1 \\
\hline Content & 55.07 & 60.58 \\
Organization & 54,02 & 70.65 \\
Vocabulary & 48.15 & 67.39 \\
Grammar & 48.17 & 52 \\
Mechanics & 50.43 & 57.39 \\
\hline
\end{tabular}

Table 3

Comparison between the highest and the lowest scores of pretest and posttest 1

\begin{tabular}{clll}
\hline No. & Explanation & \multicolumn{2}{c}{ Score } \\
\cline { 3 - 4 } & & Pretest & Posttest 1 \\
\hline 1 & Highest score & 65 & 80.5 \\
2 & Lowest score & 38.5 & 42.5 \\
3 & Average score & 51.52 & 61.65 \\
\hline
\end{tabular}


Most of the students wrote short paragraphs, and some even used google translate to transform their Indonesian writing into English without editing, which was shown from their messy paragraphs. Only a few students paid attention to spelling, punctuation, and capitalisation. In Figures 6 and 7, we can see some general mistakes that students commonly made in writing. Students had difficulty in using the verb forms or patterns correctly according to tenses, and they often add "be" before the main verbs as if "be" were always part of verb phrase like in "it is very rarely occurs", ".... was take a rest" (Figure 6). In the Indonesian language, no verb forms are used in sentences based on tenses, so it can be said that Indonesian has simpler rules than English.

Students often shortened words, for example, the word "you" into " $u$ ", "your" into "ur" and "please" into "pls", and their vocabulary was still limited. They paid less attention to the functions and locations of parts of speech in sentences, and cared less to suffixes that can help indicate the categories of parts of speech, for example "I am very surprises", "a firmly figure in my life" (Figure 6), and "how me appreciate" (Figure 7). Some still used lowercase for 'I,' for example "here i also learn" (Figure 7) and did not capitalise the initial letter of the first word in each sentence and other letters that should be capitalised for example "in bundaran besar Palangkaraya" (Figure 6). On the contrary, some capitalised letters should be in lowercase, like in the title "Angel Without Wings" (Figure 7). It was clear that the teacher had not given enough emphasis on those mechanics because they were seen as minor errors. There were some misusages of prepositions like in "After for 7 years ago..." (Figure 6), but prepositions would be better learned through context because there is no fixed rule for prepositions, so while reading texts, they were advised to pay attention to prepositions.

\section{Thank You My Father}

Posted by

Today is Father's Day. Already for 7 years ago my father passed away to heaven. I remember the first time in my childhood my father bought me a toy in bundaran besar Palangkaraya. I am very surprises and happy for this opportunity because it is very rarely occurs. My father was a very intelligent man in my life, I remember when I was in grade 5 elementary school when I forgot to do my homework, my father certainly helped to teach me how to do my homework. My father was a firmly figure in my life. One time when I was fighting with my sister, my father who actually was take a rest, suddenly come to arbitrate us and then scold and punish us. I can feel his love through his real actions, his caring and his assertive. Happy Father's Day Bapa, I love you and I miss you bapa...

Figure 6. A student's draft before revision

\section{Angel Without Wings}

Posted by

Nurse is a profession that work, because we can help many of people with this profession, Safety is priority for them that work in the morning, afternoon and in the evening, leaving family for patient, this not only about salary that we get. But, here i also learn about many things that how me appreciate other person, we must always have nice attitude, we have to tolerant and have empathy. For me, nurse is a amazing job :D

Figure 7. A student's draft before revision 


\section{Cycle Two}

Planning and action. In addition to solving the weaknesses in cycle 1, this cycle was intended to give more writing practice to students in developing their skills in using language. The topics were more diverse including the topics on nursing/medical field. Before uploading the work, the students were allowed to make drafts on their computer or gadget and post them when they were finished. The teacher brought a few samples of descriptive texts about general topics and nursing and medical subjects written and uploaded by some eloquent bloggers from the website to discuss and analyse in class.

Observation and reflection. At the end of cycle 2, a test was carried out, and the results were satisfying because the average scores for each writing component were above 60 (Table 4), while the students' average score of writing, covering all components, was over 65 (Table 5).

Table 4

Students' average scores of pretest and posttest 1 and 2 viewed from each writing component

\begin{tabular}{llll}
\hline Component & \multicolumn{3}{c}{ Average score } \\
\cline { 2 - 4 } & Pretest & Posttest 1 & Posttest 2 \\
\hline Content & 55.07 & 60.58 & 67.83 \\
Organization & 54,02 & 70.65 & 72.50 \\
Vocabulary & 48.15 & 67.39 & 66,74 \\
Grammar & 48.17 & 52 & 62.61 \\
Mechanics & 50.43 & 57.39 & 68.70 \\
\hline
\end{tabular}

There was an improvement in every writing component except vocabulary that declined almost by 2 points. During the learning process in this study, students were expected to learn vocabulary from context, but it seems that the conventional way of enriching vocabulary by memorising should also be employed. Students might need to write down new vocabulary and look up the meaning in a dictionary.

Table 5

Comparison between the highest and the lowest scores of pretest, posttest 1 and 2

\begin{tabular}{lllll}
\hline No & Explanation & \multicolumn{3}{c}{ Average score } \\
\cline { 3 - 5 } & & Pretest & $\begin{array}{l}\text { Posttest 1 } \\
\text { (cycle 1) }\end{array}$ & $\begin{array}{l}\text { Posttest 2 } \\
\text { (cycle 2) }\end{array}$ \\
\hline 1 & Highest score & 65 & 80.5 & 90 \\
2 & Lowest score & 38.5 & 42.5 & 49 \\
3 & Average score & 51.16 & 61.54 & 67.28 \\
\hline
\end{tabular}

Both the lowest and the highest score levels showed an improvement, but the improvement in the lowest score level was small. Seeing the results that revealed a gap between the highest score and the lowest score in each cycle, the 
teaching techniques and strategies apparently need to be intensified, especially when dealing with the students with lower test scores.

\section{Discussion}

The students' writing achievement seen from the average scores of the final test (posttest 2) showed an improvement. From the observations, it was found out that the participation of students in writing blog posts and discussion was pretty high. It is in line with what Chawinga (2017) found in her study whereby "students actively participated in blog discussion" (p. 11). The reasons for students' strong motivation in getting involved in the blogging activity were revealed in the interview.

Most of the students stated that they not only learned and practised their writing skill on the social network, MyEnglishClub, but they also had fun at the same time because they could interact with other members from different countries. The comments or feedbacks from the website members were mostly constructive. McBride and King (2010) stated that "the global audience suggested by blogs permits a wider audience to provide positive comment and reaction to students" ( $p$. 5). Others said that they felt secured for not exposing their real identity so that they could express themselves better without feeling discouraged or shy. Abu Bakar and Ismail (2011) pointed out that blogging "encouraged students to go beyond classroom and interact with people" (p. 47).

The activity allowed flexibility in accomplishing and submitting assignments using smart phones and other gadgets. Chawinga (2017) stated that "students could post their assignments anytime without being worried that they could find the lecturer's office closed or, there was nothing like racing against the official working hours" (p. 10). Also, they can draft, revise, edit, and publish their writing as well as reading and giving comments on others' work or responding to the comments on their posts. It reinforces the conclusion made by Nepomuceno (2011) that "blogging is not just about the activity of writing but it involves the sharing of experiences and information as well as responding to what others have written" (p. 96).

The process genre approach used in the study also contributed to the improvement of students' writing skill (Assaggaf, 2016; Sari \& Saun, 2013), and the teacher played a supporting role in the learning process. When discussing and analysing the texts, the teacher assisted students in gaining required linguistic knowledge and showed them the stages of making a good writing as Badger and White (2000) concluded that teachers facilitate "learners' progress by enabling appropriate input of knowledge and skills" (p. 160).

However, not every student found blogging interesting. Some older students, especially the ones who already had a family, showed less interest in blogging resulting in less participation. A few less active students said that they also had issues with time management, and were not familiar with the mode of Internet communication and did not like writing, even writing in the Indonesian language. They admitted that English was still difficult to learn, and writing in English was challenging. 


\section{Conclusion}

It can be concluded that the combination of blogging as the assignment for writing practice and the process genre approach for teaching writing has improved the students' writing skill. By introducing learning activities utilising the Internet technologies it is hoped that students will become autonomous learners who will keep on learning even after the class ends. Although the findings of the action research cannot be generalised from one class to the other, fellow teachers may use some of the findings as the considerations in choosing or modifying their teaching techniques and strategies in their classrooms. Teachers should be able to keep pace with the rapid development of technologies, especially the Internet technologies, and make optimal use of them for English teaching and learning.

\section{References}

Abu Bakar, N., \& Ismail, K. (2011). Using blogs to encourage ESL students to write constructively in English. AJTLHE Journal, 1(1), 45-57.

Armstrong, K., \& Retterer, O. (2008). Blogging as L2 writing: A case study. AACE Journal, 16(3), 233-251.

Ary, D., Jacobs, L. C., \& Sorensen, C. K., \& Razavieh, A. (2010). Introduction to Research in Education ( $8^{\text {th }}$ ed.). Belmont, CA: Wadsworth.

Assaggaf, H. T. (2016). A process genre approach to teaching report writing to Arab EFL computer science students. International Journal of English Linguistics, 6(6), 8-18.

Badger, R., \& White, G. (2000). A process genre approach to teaching writing. ELT Journal, 54(2), 153-160.

Brown, H. D. (2001). Teaching by principles: An interactive approach to language pedagogy $\left(2^{\text {nd }}\right.$ ed.). White Plains, NY: Pearson Education.

Chawinga, W. D. (2017). Taking social media to a university classroom: Teaching and learning using twitter and blogs. International Journal of Educational Technology in Higher Education, 14(3), 1-19.

Jacobs, H. L., Zinkgraf, S. A., Wormuth, D. R., Hartfiel, V. F., \& Hughey, J. B. (1981). Testing ESL composition: A practical approach. Rowley, MA: Newbury House.

Jennings, D., Surgenor, P., \& McMahon, T. (2013). Education theory: Constructivism and social constructivism in the classroom. Retrieved from http://www.ucdoer.ie/index.php/Education_Theory/Constructivism_and_So cial_Constructivism

Kilickaya, F. (2004). Authentic Materials and Cultural Content in EFL Classrooms. The Internet TESL Journal, 10(7). Retrieved from http://iteslj.org/Techniques/Kilickaya-AutenticMaterial.html

Martindale, T., \& Wiley, D. A. (2004). An introduction to teaching with weblogs. Retrieved from http://teachable.org/papers/2004_blogs_in_teaching.pdf

McBride, R., \& King, V. (2010, March). Improving writing skills using blogging in the elementary classroom: Choosing tools they use. Paper presented at Society for Information Technology \& Teacher Education International Conference (SITE), San Diego, California. 
Nepomuceno, M. M. (2011) Writing online: Using blogs as an alternative writing activity in tertiary ESL classes. TESOL Journal, 5, 92-105.

Nunan, D. (1999). Second language teaching and learning. Boston, MA: Heinle \& Heinle.

Ozdemir, E., \& Aydin, S. (2015). The effects of blogging on EFL writing achievement. Procedia-Social and Behavioral Sciences, 199, 372-380.

Reppen, R. (1995). A genre-based approach to content writing instruction. TESOL Journal, 4(2), 32-35.

Sari, P. P., \& Saun, S. (2013). Teaching writing by using the process-genre approach at junior high schools. Journal of English Language Teaching, 2(1), 1-10.

Vygotsky, L. (1978). Mind in society: The development of higher mental processes. Cambridge, MA: Harvard University Press.

Zhang, D. (2009). The application of blog in English writing. Journal of Cambridge Studies, 4(1), 64-72. 